\title{
Inteligência artificial: o Frankenstein contemporâneo?
}

\author{
JUNIOR CUNHA ${ }^{1}$
}

O medonho monstro criado por Mary Shelley, na primeira metade do século XIX, ainda é uma fonte rica para pesquisas literárias e, mais ainda, base para produções, desde HQs a cinematográficas, que levam a ficção da autora londrina a extremos. A criatura de Victor Frankenstein, ora é pintada com tons mais sombrios, ora ainda mais horripilante e, não raras vezes, com traços que ressaltam certo antropomorfismo, ainda mais do que feito por Shelley.

Malgrado todo o encanto provocado tanto pela obra de Shelley quanto pelas incontáveis releituras já produzidas, há algo em Frankenstein que subjaz o poder de atração característico de obras ficcionais, ainda mais de ficções cientificas. A obra em questão é creditada como a primeira do gênero: a equiparação do homem com os deuses; de modo que Victor Frankenstein, o cientista que cria o monstro na obra de Shelley, pode ser visto como que um Prometeu moderno.

A partir da obra de Shelley podemos dizer que há uma reformulação do que chamamos de "mito de Prometeu"; enquanto na Teogonia de Hesíodo tínhamos um titã com a capacidade de criar; já, em Frankenstein, temos um ser humano com a mesma capacidade. A diferença elementar entre a narrativa pré-socrática e a narrativa moderna suscita uma série de questionamentos, entre eles, destaque-se, sem sombra de dúvida, uma problemática profundamente entusiasmante: seriamos capazes de criar um ser tanto quanto ou mais complexo do que o ser humano?

De acordo com a narrativa de Hesíodo, Prometeu é condenado por Zeus a ser acorrentado em um penhasco e ter o seu fígado devorado por uma águia todos os dias como punição por ter roubado o fogo dos deuses e entregue aos humanos. No contexto mítico da Teogonia, o fogo que é roubado dos deuses representa o conhecimento que é dado aos seres humanos. Em resumo, é o fogo roubado por Prometeu que fez dos humanos seres detentores de conhecimentos, ou melhor, seres que se distinguem dos demais devido a sua inteligência.

A capacidade de processarmos informações a uma velocidade quase incalculável e disso obtermos conhecimentos concretos sobre o mundo que nos cerca e, mais ainda, os relacionar para chegar a novos patamares de conhecimento, a grosso modo, descreve o que é a inteligência humano. Somos, consequentemente, dotados de uma alta e complexa capacidade de aprendizado.

'Licenciado e Mestrando em Filosofia pela UNIOESTE com Bolsa CAPES (DS). ORCID: http://orcid.org/oooo-ooo2-2069-1924. E-mail: juniorlcunha@hotmail.com 
O monstro criado por Victor Frankenstein, na ficção de Shelley, apresentou a mesma capacidade de aprendizado dos seres humanos, ocupando literalmente o centro da narrativa. Quer dizer, o monstro conta a sua história, o desenvolvimento da sua mente e como aprendeu a falar e a ler. Com isso, a sua mente se abre a novas perspectivas e passa a compreender a configuração da sociedade em que se vê colocado. Este processo pelo qual o monstro de Frankenstein passa, do movimento de aprendizagem à compreensão de fazer, parte de uma estrutura social. Isso o leva a introspeção e a questionar-se sobre quem é seu criador, o porquê de ter feições tão horríveis e sobre seu próprio eu. Pode-se apontar, a partir daí, o nascimento de uma consciência de si.

Em junho de 1963, Arthur Clarke escreveu o conto Frankenstein ao Telefone, em que narra a discussão de um grupo de amigos sobre o fato de todos os telefones do mundo terem tocado a uma hora e cinquenta da manhã. Um dos personagens, o Dr. Jonh Willians, apresenta sua tese sobre o ocorrido; segundo ele, há uma analogia entre a central telefônica automática e o cérebro humano, dado a semelhança daquela com este.

Na sequência, o Dr. John, compara a central telefônica automática com um bebê; as campainhas que tocaram todas ao mesmo tempo indicaram o choro do recém-nascido e os acontecimentos estranhos que passaram a ocorrer, como acidentes industriais e o comportamento irregular dos bancos corroboravam sua tese. Segundo o Dr., assim como os seres humanos possuem fases, como o nascimento, e, depois disso, viraria bebê e passa a quebrar coisas, o mesmo estava ocorrendo com a central telefônica. Mais: segundo o Dr., chegaria um ponto em que a central atingiria a consciência, dado a quantidade de dados e informações à disposição e o modo como tudo se interligava.

O conto escrito por Clark nos remete a uma provável nova reformulação do mito de Prometeu, este agora não ficcional; trata-se de um dos grandes avanços científicos-tecnológicos da humanidade, o constante processo de desenvolvimento da inteligência artificial (IA). Isso permite apontar, por exemplo, a IA como um possível Frankenstein contemporâneo. É evidente que o Frankenstein de nosso tempo ainda não ganhou "vida", mas podemos dizer que se encontra em processo de construção, assim como o monstro de Victor Frankenstein na mesa fria de seu laboratório.

Mesmo com os avanços obtidos nas últimas décadas, temos que admitir: podemos não estar tão próximos de criar uma inteligência e/ou consciência tanto quanto ou mais complexa que a dos seres humanos. É preciso, no entanto, reconhecer que já temos processadores que atingem velocidades cada vez maiores e capazes de cruzarem bancos de dados maiores que o Everest, por exemplo. Talvez o que nos falte é conseguirmos a "descarga elétrica" que deu vida às diversas partes de corpos humanos costuradas que fez nascer o monstro Frankenstein. Até lá, porém, 
precisaremos responder: estaremos mais próximos de Victor Frankenstein e sua criatura horripilante ou de Prometeu e os seres humanos?

\section{Referências}

ARAÚJO, A. F; ALMEIDA, R; BECCARI, M. (Orgs.) O mito de Frankenstein: imaginário e educação. São Paulo: FEUSP, 2018.

CLARKE, A. C. "Frankenstein ao telefone". In: CLARKE, A. C. O vento solar. Trad. Leonel Vallandro. São Paulo: Círculo do Livro, 1972.

Submissão: 09. 04. 2021 / Aceite: 15. 07. 2021 